\title{
Project-Based Learning: \\ Road to Make Connection between Concept and Skills in Mathematics Manipulative Media
}

\author{
Tri Candra Wulandari, Kawakibul Qamar \\ Department of mathematics education, Kanjuruhan University \\ fikri.chan@unikama.ac.id, ikings94@unikama.ac.id
}

\begin{abstract}
Mathematics is based on certain concepts and rules, teachers must motivate students to be able to express the concept in the real world yet. not all mathematical material is abstract or all mathematical material can be made real. Therefore, there needs to be a bridge between the abstract world and the real world. Mathematics Manipulative Media is one of the subjects in mathematics education program at Kanjuruhan University. This subjects is given to third year students this class started using Project-Based Learning (PBL). PBL was design to teach the student with combining concept and student skills. These skills include communication and presentation skills, organization and time management skills, research and inquiry skills, selfassessment and reflection skills, group participation and leadership skills, and critical thinking. All of these skills are needed for their life in their society. Implementation of PBL in this manipulative media class is done using 4 stages, namely the delivery of rules and concepts, the delivery of ideas, product/creation solution and problem conclusion. While the skills involved at each stage are communication and presentation skills, time and organizational management skills, searching and discovering skills, selfassessing and reflection skills, leadership and lead skills, and critical thinking.

Keywords: Project-Based Learning, Mathematics Manipulative Media
\end{abstract}

\section{INTRODUCTION}

Teaching mathematics same likes getting students into the world of mathematics. The world of mathematics that students will see depends on how teachers bring them. If the teacher only shows mathematics in the abstract world, students only see about the abstract of mathematics. Conversely, if the teacher shows mathematics in the real world, students will see the math in real terms. Mathematics is based on certain concepts and rules, teachers must motivate students to be able to express the concept in the real world yet (Schoenfeld, 1992). However, not all mathematical material is abstract or all mathematical material can be made real. Therefore, there needs to be a bridge between the abstract world and the real world. One way that teachers can do in bridging between the abstract world and the real world is through media, i.e. concrete media or manipulative media. Utilizing the media on learning activities appropriately expected to be more ease in delivering learning messages to students (Hidayati, 2007) 
Mathematics Manipulative Media is one of the subjects in mathematics education program at Kanjuruhan University. This subjects is given to third year students, this class started using Project-Based Learning (PBL). Project-Based Learning (PBL) is an innovative approach to learning that teaches a multitude of strategies critical for success in the twenty-first century. Students drive their own learning through inquiry, as well as work collaboratively to research and create projects that reflect their knowledge. From gleaning new, viable technology skills, to becoming proficient communicators and advanced problem solvers, students benefit from this approach to instruction (Bell, 2010). Beside that, PBL allows students to collaborate, create an authentic learning environment where students are actively involved in completing project tasks independently and work with teams in integrating mathematical concepts with the real world (Kamdi, 2010; Rais, 2010). PBL environments shift the focus of learning away from "correct, indisputable" answers to the process of converging on solutions, they create a dynamic space where power, authority, and control are necessarily shared between the teacher, students, and disciplinary practices (Rogers, 2011).

Project-based learning is required in the learning of manipulative media courses. This is caused by many things, among others (1) one of the goals of manipulative media lectures is to produce products in the form of manipulative media, (2) project completion process requires good team collaboration, (3) manipulative media lectures not only make but will start from requirements analysis process, presentation of design, manufacture and presentation of media usage. So it requires independence and good teamwork. PBL teaches students the skills needed when students become part of the community. These skills include communication and presentation skills, time and organizational management skills, searching and finding skills, self-assessing and reflection skills, leadership and lead skills, and critical thinking. In addition, stated that effective online projects encourage students to work on a problem in depth, rather than covering many topics briefly. Students also engage in learning what is required to solve a problem or complete a project, rather when the teacher decides in the predetermined curriculum. Both literatures as being important tools to improve learning (Goodman, 2010).

The lecture activities are purely student-oriented, the lecturers act as facilitators and motivators to the students. Project-Based Learning (PBL) is a student-driven, teacherfacilitated approach to learning. Learners pursue knowledge by asking questions that have piqued their natural curiosity (Bell, 2010. The results showed that $90 \%$ of students who follow the learning process by implementing project-based learning believe and optimistic to implement project-based learning in the world of work and can improve academic achievement (Rais, 2010). A project-based learning in the classroom Learning Media Manipulative allows students to investigate questions, propose hypotheses and explanations, discuss their ideas, challenge the ideas of others, and try out new ideas (Krajcik, 2006).

The phase applied to the PBL in the Media class uses the phase of Mergendoller (English, 2013) consisting of three main phases: 1) project/problem launch, 2) guided inquiry and product/solution creation, and 3) project/problem conclusion. However, in the implementation of PBL in the Media class, researchers modified the PBL phase. This modification is done in accordance with the needs during the lecture took place. This modification lies in the implementation of PBL, that is, before entering the first phase, the 
lecturer gives the rules of implementing the PBL while explaining the concept of manipulative media. This needs to be done in order to have a common perception of media concepts between lecturers and students. The second modification is done in the first phase, that is when the problem is delivered, the lecturer gives space to the students to criticize the idea of the group that the presentation. Critical thinking is done to see how much mastery of mathematical concepts and concept of media ideas from the group.

So, the implementation of PBL in this manipulative media class is done using 4 stages, namely the delivery of rules and concepts, the delivery of ideas, product/creation solution and problem conclusion. While the skills involved at each stage are communication and presentation skills, time and organizational management skills, searching and discovering skills, self-assessing and reflection skills, leadership and lead skills, and critical thinking.

\section{RESEARCH METHOD}

This study aims to describe the implementation of PBL which links the four skills with mathematical concepts held by students. In accordance with these objectives, the researchers used a qualitative approach. Description of learning using PBL is implemented in the even semester of the academic year 2016/2017 on lectures Media Manipulative. Students that involved in this PBL consist of 38 students who are divided into 12 groups with the number of members per group of 3 to 4 students. The determination of the group is done by the students with the consideration of the location of the residence so that the students there is no reason the project is not completed because the residence is far apart.

The project theme is a manipulative medium for explaining mathematical concepts in junior high school or high school. Topics or materials are chosen by students to be made free media, in accordance with the above provisions. When the presentation of media ideas are in the same group, one will be chosen by the concept of conceptualization, the clarity of the media creation plan and the skill to explain the conceptual linkage with the media to be created.

Each group will perform 3 presentations, namely (1) the presentation of ideas includes the mathematical concepts that will be created by the media and the reasons why to create the media with the concept, (2) the presentation of material design and the estimated material resource acquisition. At this stage, the lecturer advises students to use the materials around them, which are still usable and do not cost much, (3) product presentation and how to use it. However, if there are any shortcomings or errors of each presentation, the group should repeat the presentation. It is intended that the group really master the concepts, designs, types of materials to be used, the process of making the media and how the media work.

\section{RESULT}

The PBLs performed in the media class produce 11 manipulative media, TUTORIAL, MOBATRY, POSAN UCUT, HUBARDUT, PATROLI, TEKOOR, Sempoa Logaritma, Lompat Kartun, PASUTRI, BOGSILING (Bongkar Pasang Garis Singgung Lingkaran). At this stage of the discussion, we will describe four stages of PBL applied to media lectures, namely the delivery of rules and concepts, the delivery of ideas, product/creation solutions and problem conclusion. In the first stage, the lecturer takes an important role to 
convey the rules of PBL implementation and the delivery of the concept of manipulative media. Media recognition activities were conducted during two meetings. At this stage the lecturer explains the concept of media, media characteristics and media elements. This stage is an important stage to be conveyed so that there will be similar perception between lecturer and student about manipulative media. The teacher's primary role in PBL is to structure activities to stimulate learning through scaling, feedback, guidance and prompts for thinking (English, 2013).

At the second meeting, besides the lecturers explained about the criteria of good media, in this second meeting formed a group to implement the project. As already stated, the group formed is 12 groups, with members of 3 to 4 students. Many groups are determined by lecturers with the objective of project completion effectiveness, in the hope that all students are involved in project completion. Project-based instruction is innovative by its emphasis on cooperative learning. Cooperative learning encourages active engagement by the students in learning, and it also builds critical skills needed in today's workplace. Additionally, students create tangible results to represent what they have learned (Goodman, 2010).

After the lecturer conveys the concept and rules of PBL, the lecture enters the second stage, namely the delivery of the problem. At this stage, students are more directed at the presentation of ideas. Of course, the idea of the media to be created departs from the analysis of problems that students have previously done with their groups. This stage is held during three meetings. At this presentation stage, the lecturer gives space to the students to criticize the idea of the presenter group, related to the feasibility level of the concept for the media, the difficulty of making the media related to the concept, and the source of materials and the cost used. In addition, at this stage, each student must be able to apply communication and presentation skills. The idea presented is not merely an idea the media will make. However, there will be a shared decision-making process within the classroom, whether the idea is worthy of being a project or not. Consideration of eligibility is reviewed from the media's novelty, the presence or absence of media similarity with examples-media on YouTube or other social media, the level of difficulty and cost an estimated time required.

From 12 presentation groups, there were 2 groups that had to replace the mathematical concepts that the media would make. In addition, there was one group that fell in the preparation of this project; this is because during two weeks from the time agreed to the presentation of ideas, the group was not present. It is evident that there are skills that the non-presentation groups cannot meet namely presentation skills, time management skills and problem-solving skills.

Next is the third stage, the product/creation solution. After the group conveys the idea, the next stage is to make the product in accordance with the ideas that have been presented. Before each group makes a product, each group presents a draft solution of an idea that has been previously submitted. This presentation is done in order to see the suitability of the design with the ideas that have been submitted. At this stage in addition to the skills to make presentations, the skills required are the searching and finding skills. 
This skill is absolutely necessary because the student is not printed not just giving the idea, but how he is able to realize his idea in accordance with the concept needed. They have access to people and information from the real world, and they develop a closer relationship to the real-world context of problems and projects. The connections to real people, events, and problems in the world are related to their interests, their intellect, and their participation (Krajcik, 2006). These skills will be very useful when they jump into the community, by having the skills to find and find solutions, students not only convey the discourse but also big on the act of providing a real solution of the problems faced.

This fourth stage is the final stage in the PBL in the media class, namely the problem conclusion stage. At this stage, each group has completed the media and is ready to be presented how to use it. Presentation of media is done by way of demonstration media usage. This demonstration was held twice, the first presentation of the media, when the group presented the media, another group criticized the media product that has been produced, which is criticizing the attraction related to color, writing, letters and things related to visualization. In addition, another thing that is criticized is the application of the concept of using the media, whether the media can be applied to understand the concept or not. If the group gets suggestions regarding changes in color, shape, text or matters relating to visualization or clarity of concepts, then the group should revise the media it has created and re-present its media revision results. This first demonstration involves presentation skills, collaboration, time management and critical thinking. Presentation skills will be visible from how students explain media usage, collaborative skills will appear from the form of communication between group members during a presentation, whether it is dominated by only one person or all group members understand the concept used in the media. Time management will be evident from the timeliness of product completion. There is no reason the media is not finished yet. While the critical thinking skills appear from how students discussed critiquing media presented in front of the class.

\section{CONCLUSION:}

Implementation of PBL in the class Media Manipulative can make connection between mathematical concepts and skills that needed in society. Collaboration between skills and concepts is reflected in every stage of PBL implementation in the classroom. Understanding of mathematical concepts and communication skills is apparent when students present the idea of a media plan to be created. Critical thinking looks when students be criticize each group of presentations. Self-assessment and reflection skills looks when students and their groups can measure their ability to create manipulative media, while reflection skills are evident from the group's willingness to revise the media. Research and inquiry skills appear from how students analyze media needs and relate to the mathematical concepts needed. While the participation and leadership skills group is visible from the role of each group member in collaborating with all team members to produce the media. Finally, organization and time management skills are evident in the group's ability to complete the media on time, assigning tasks to each member of the group so that at the time of presentation the resulting media outcome is a team's collaboration, not an individual work. Although PBL is project, there is no harm to applied PBL for 
another subject. So, from this research, we recommended applied PBL for Statistics, Real Analysis or Education subject.

\section{REFERENCES}

Bell, S. (2010). "Project-Based Learning for the 21st Century: Skills for the Future," Clear. House A J. Educ. Strateg. Issues Ideas, vol. 83, no. 2, pp. 39-43

English, M. C. and A. Kitsantas. (2013). "Supporting Student Self-Regulated Learning in Problem- and Project-Based Learning," Interdiscip. J. Probl. Learn., vol. 7, no. 2

Goodman, B.. (2010). "Project-Based Learning Why Use It?,"

Hidayati, K., D. Bondan, M. Susanti, E. Arliani, and R. Subekti. (2007). "Upaya Menumbuhkan dan Meningkatkan Keterampilan Mahasiswa Prodi Pendidikan Matematika FMIPA UNY dalam Membuat Media Kartun untuk Pembelajaran Statistika dan Peluang di SMP dan SMA," Phytagoras, vol. 3, no. 2, pp. 51-64

Kamdi W. (2010), "Implementasi Project-Based Learning di Sekolah Menengah Kejuruan,” vol. 17, no. April, pp. 98-110.

Krajcik, J. S. and P. C. Blumenfeld. (2006). "Project-Based Learning," STEM Proj. Learn.

Rogers, M. a P., D. I. Cross, M. S. Gresalfi, and ...,. (2011). "First Year Implementation of a Project-Based Learning Approach: the Need for Addressing Teachers'Orientations in the Era of ...," Int. J. ..., pp. 893-918

Rais, M.. (2010). "Model Project Based-Learning Sebagai Upaya Meningkatkan Prestasi Akademik Mahasiswa," J. Pendidik. dan Pengajaran, vol. 43, no. 3, pp. 246-252.

Schoenfeld, A. H.. (1992). "Learning To Think Mathematically: Sense-Makingin Mathematics," D. Grouws (Ed.), H a n d b o o k f o r R e se a r c h o n M a t h e m a t i cs T e a ch in g a n d L e a r n in g (pp. 334-370). New York MacMillan. 